UDC: 930:929 Lomonosov 930:929 Karamzin

Ђорђе Ђурић

Универзитет у Новом Саду

Филозофски факултет

Одсек за историју

djdjuric@gmail.com
Оригиналан научни рад

примљено: 15. април 2013

прихваћено: 1. октобар 2013

\title{
ПИСЦИ РУСКЕ ИСТОРИЈЕ - М. В. ЛОМОНОСОВ И Н. М. КАРАМЗИН*
}

Сажетак: У раду се разматра историографска делатност Михаила Васиљевича Ломоносова и Николаја Михајловича Карамзина. Поред кратког осврта на њихове биографије и делатност на другим пољима руске културе и науке обрађују се њихов историографски метод, извори који су им били доступни и које су користили и интелектуални утицаји који су креирали њихове ставове. Ломоносов, који је своје најзначајније историографско дело Древна руска историја написао средином 18. века, био је огорчени противник теорије о норманском пореклу Руса, док је Карамзин, који је своје дванаестотомно дело Историја руске државе објавио у другој и трећој деценији 19. века, ову теорију у потпуности прихватио.

Кључне речи: Михаил Васиљевич Ломоносов, Николај Михајлович Карамзин, историја руске историографије, историја руске културе 18. и 19. века, Варјашко питање, Катарина Велика, Александар I.

\section{Ломоносов}

Михаил Васиљевич Ломоносов једна је од најславнијих личности руске науке. Обележио је њен развој на пољима хемије, геологије, географије, физике и филозофије. У руској култури великог одјека имале су његове Руска граматика и реформа књижевног језика, али и преводи и књижевна дела и дела ликовне уметности. Историјом се бавио само узгредно, али је његов рад на овом пољу имао велики значај. Написао је дело Древна руска историја, од постанка руског народа до краја владавине великог кнеза Јарослава Првог или до 1054. године. ${ }^{1}$ Међутим,

\footnotetext{
* Текст је настао као фазни резултат рада на пројекту Војвођански простор у контексту европске историје (број 177002) Министарства просвете, науке и технолошког развоја Републике Србије.

${ }^{1}$ М. В. Ломоносов, Древняя российская история от начала российскаго народа до кончины великаго князя Ярослава Перваго или до 1054 года, сочиненная Михайлом Ломоносовым статским Советником, Профессором Химии и Членом Санкт-Петербургской Императорской и Королевской Шведской Академий наук, I-II, Санктпетербург 1766.
} 
већег трага у руској историјској науци оставио је његов спор са Герхардом Фридрихом Милером око Варјашког питања у оквиру Академије наука у Петрограду. Остао је упамћен као утемељивач националне науке, који се борио против превласти странаца у оквиру Академије.

Михаил Васиљевич Ломоносов рођен је 1711. у селу Мишанинскаја у Архангелској губернији на крајњем северу Русије, у породици сиромашног рибара. Почетно образовање добио је од локалног ђакона. Да би наставио школовање (али, извори кажу, и да би избегао намењену му женидбу), децембра 1730. кренуо је у Москву пешке по најсуровијој зими. Почетком 1731. примљен је у тада славну Славјано-греко-латинску академију. Блистави таленат омогућио му је брзо напредовање у школи. Већ 1734. одлази у Кијев и наставља школовање у Кијевомогиљанској академији, на којој је већ био превладао барокно-рационалистички дух Теофана Прокоповича. Следеће године са најбољим полазницима ове школе послат је да настави школовање у оквиру Академије наука у Петрограду. Убрзо је као државни питомац упућен у Немачку да изучава науке потребне за рударство и металургију. Три године је провео у Марбургу под надзором Кристијана Волфа 2 , филозофа, математичара и физичара, чије је филозофске погледе на историју ценио и славни Василиј Никитич Татишчев. Потом Ломоносов студије наставља у Фрајбургу као ученик угледног хемичара и металурга Хенкела, и на крају се годину дана усавршавао у Холандији. Све то време писао је песме и учио европске језике и теорију књижевности. Током студија оженио се Немицом Елизабетом Цилих. У Петроград се вратио 1741. године, као формиран научник. Одмах је примљен за асистента у Академији а 1747. постао је професор. Већ првих година рада у Академији објавио је неколико радова из области минералогије. У то време почео је борбу да настава у Академији буде одржавана на руском језику, а не на немачком или латинском. Током 1749. и 1750. у оквиру Академије водио је велики спор са Милером око Варјашког питања. Поред бројних радова из области хемије, физике, астрономије и металургије који су поставили темеље ових наука у Русији, Ломоносов се вредно бавио и хуманистичким наукама. ${ }^{3}$ Објавио је уџбеник реторике, ${ }^{4}$ потом је 1755. изашла његова Руска граматика, ${ }^{5}$ која је била основ за

\footnotetext{
${ }^{2}$ Кристијан Волф (Christian Wolff, 1679-1754), немачки филозоф, очигледно врло популаран у Русији онога времена, будићи да је 1740-их година на руски преведено више његових дела, међу којима су Волфијанска експериментална физика, Разумне мисли о силама људског разума и њиховом исправном употребљавању у разумевању истине (Христиан Вольф, Волфианская експериментальная физика (превод М. В. Ломоносова), Санктпетербург 1746; Разумные мысли о силах человеческого разума и их исправном употреблении в познании правды (превод с латинског), Санктпетербург 1765). Ломоносову су били доступни и непреведени Волфови радови: Philosophia rationalis, sive logica (1728); Philosophia prima, sive Ontologia (1729); Cosmologia generalis (1731); Psychologia empirica (1732); Psychologia rationalis (1734); Theologia naturalis (1736-1737); Philosophia practica universalis (1738-1739); Jus naturae and Jus Gentium (1740-1749); Philosophia moralis, sive ethica (1750-1753).

${ }^{3}$ Допринос Ломоносова на пољу природних наука у Русији се сматра значајнијим од његовог рада у хуманистичким наукама, али његова делатност у природним наукама неће бити тема овог нашег осврта на његов рад.

${ }^{4}$ М. В. Ломоносов, Краткое руководство к красноречию, В коей содержсится Риторика, Санктпетербург 1748.
} 
реформу књижевног језика који се тада приближио народном. Исте године израдио је пројекат и активно се залагао за оснивање знаменитог државног универзитета у Москви, који и данас носи његово име. Тих година започео је и рад на руској историји, која је објављена тек након његове смрти 1766. године. Поред свега поменутог Ломоносов је стигао да напише више дела поезије и ораторске прозе, али и теоријских радова који су битно утицали на развој поетског стила у Русији. Превео је на руски велики број дела или одломака античких писаца (Хомера, Вергилија, Лукреција, Сенеке и др.). Аутор је више мозаика, међу којима и чувеног портрета Петра Великог и Битке код Полтаве. ${ }^{6}$

Будући да је био пореклом из редова државних кметова, Ломоносов је добро разумео проблеме нижих слојева руског друштва и сматрао да је економски напредак Русије могућ само уз велике реформе. Те реформе, по њему, биле би могуће уз јачање просвећеног апсолутизма, чији је био одлучни присталица.

Смисао бављења историјом Ломоносов, као и Татишчев, а под утицајем Волфа, види у њене две основне функције. Прва је практична. Историја треба да буде ризница искуства. По њему, у прошлости „сваки појединац, од краља до простог човека“, може наћи примере како да се понаша у одређеним ситуацијама. Друга функција историје је васпитна: она треба читаоца да наводи на добра дела. ${ }^{7}$

Такође под утицајем Кристијана Волфа прихватио је елементе цикличног модела историје. По њему, сваки народ има период успона и „цветања“, а потом период пада и „сумрака“. „Једни народи настају, када други нестају; нестанак једнога народа пружа могућност настанка другог“, пише он у Древној руској историји. ${ }^{8}$ Међутим, у његовој теорији налазимо и елементе спиралног успона историје: „После сваког пада и несреће следио је успон, већи од претходног“, наставља он у истом делу. ${ }^{9}$ Занимљиво је да у циклусима историје пореди Римско царство и Русију, налазећи да периоду власти римских „краљева“ одговара период владавине самосталних кнежева у Русији. Периоду републике у Риму налази пандан у периоду феудалне раздробљености и самосталних градова у Русији, и на крају Римска империја „по свему подсећа“, каже он, на време владавине московских царева самодржаца. ${ }^{10}$

Дело Михаила Васиљевича Ломоносова на пољу историје и историографије, обележио је његов одсечан и чврст антинорманистички став.

\footnotetext{
${ }^{5}$ М. В. Ломоносов, Российская грамматика, Санктпетербург 1755.

${ }^{6}$ Живот и дело М. В. Ломоносова тема су дела сваке генерације руских научника разних области. До сада су у више наврата издана његова Сабрана и Изабрана дела, најновија су: М. В. Ломоносов, Сочинения: [В 8 т.], Москва-Ленинград 1891-1948. и М. В. Ломоносов, Полн. собр. соч.: В 10 т. Изд-во АН СССР, Москва-Ленинград 1950-1959, Т. 11, Наука, Москва-Ленинград 1983; За овај кратак приказ Ломоносовљеве биографије коришћена су дела: Летопись жизни и творчества М. В. Ломоносова, Наука, Москва-Ленинград 1961; Е. М. В. Лебедев, Ломоносов, Ростов на Дону 1997 (објављено у чувеној „Горковској“ едицији Жизнь замечательных людей).

${ }_{7}^{7}$ М. А. Алпатов, Русская историческая мысль и западная Европа, XVIII - первая половина ХІХв, Москва $1985,61-62$.

${ }^{8}$ М. В. Ломоносов, Древняя российская история..., Вступленіе, 2-3.

${ }^{9}$ Исто.

${ }^{10}$ Исто, 3-4.
} 
Најбољи пример за то је његова расправа са Герхардом Фридрихом Милером вођена под кровом Петроградске императорске академије наука од октобра 1749. до марта 1750. Повод је био планирано Милерово предавање Порекло руског имена и народа које је требало одржати на свечаној седници Академије за празник Тезоименства царице Јелисавете Петровне 1749. године. Ломоносов је жестоко напао Милерове норманистичке ставове и назвао их „увредом и хулом на руски народ“. ${ }^{11}$ Милеру је посебно замерио што је више веровао страним писцима него старим руским летописима, а уз то је сматрао да Милер није довољно знао руски језик и да није добро тумачио Нестора Летописца. Поред тога, оспоравао је Милерово тумачење да су имена првих кнежева пореклом скандинавска (Олга - Алогија; Владимир Валдемар; Всеволод - Визвалдур). Ломоносов је, као и Татишчев раније, тврдио да име Руси води порекло од словенског племена Роксолана, које је живело у степама јужне Русије. По Ломоносову, Роксолани су се заједно са Готима населили на северу, на обалама Балтичког мора, и тамо су добили име Варјази. Отуда су по њему Варјази-Руси, о којима пише Нестор, говорили словенским језиком. На основу неких топонима, он је тврдио да су Варјази-Руси некада живели и на територији Курландије, и да су становници те области њихови потомци и да они такође говоре словенским језиком. ${ }^{12}$ Ова полемика окончана је „победом“ Ломоносова, који је у време Јелисавете Петровне уживао подршку двора. Дуго су због те чињенице присталице Норманске теорије ниподаштавали аргументе Ломоносова, тврдећи да су они били само „политички подобни“, а не и научно засновани.

Рад на свом најпознатијем историографском делу Древна руска историја Ломоносов је започео 1751. године, а завршио га је између 1754. и 1758. Оно је објављено тек после његове смрти 1766 . Богату изворну основу чиниле су три групе докумената. У прву спадају антички и византијски извори (Плиније, Тацит, Птоломеј, Прокопије из Цезареје и др.), који су му били доступни и које је као одличан зналац латинског и грчког језика користио у оригиналу. У другу групу извора спадају дела пољских аутора настала од 14. до 17. века (М. Стријковског, М. Кромера, Ј. Длугоша, М. Преторија и М. Меховског) а која је користио, такође у оригиналу, при излагању о пореклу словенских народа и њихових језика. Трећу групу извора чине стари руски летописи које је Академија била сакупила, а неке од њих већ и објавила.

За разлику од претходних руских аутора, Ломоносов је велику пажњу посветио руској историји пре Рјурика. Тако је његова књига подељена на два приближно једнака дела: 1. О Русији пре Рјурика и 2. Од Рјурикове владавине до смрти Јарослава Првог (Мудрог). У првом делу пише о народима који су од давнина живели у Русији, о пореклу руског народа, његовом друштву, старој религији и сеобама, о Чудима, Варјазима „уопште“ и Варјазима-Русима, о односу Варјага и Новгородаца и доласку Рјурика у Новгород. ${ }^{13}$ Оваквом структуром дела

\footnotetext{
${ }^{11}$ В. В. Фомин, Ломоносов, Гений русской истории, Москва 2006, 226-231.

${ }^{12}$ Н. М. Рогожин, Петровские рефорьы и русская историография у: М. Ю. Лачаева, Историография истории России, до 1917. года, Москва 2004, 130-132.

${ }^{13}$ М. В. Ломоносов, Древняя российская история..., 5-54.
} 
прејудицирао је свој антинормански став, показујући да Словени - Руси, имају дугу историју у којој су изградили свој језик и институције пре појаве Варјага. У овом делу књиге он каже да народи настају у процесу „сеоба и странствовања“, приликом којих су разне групе помешане и нема „чистих“" народа. ${ }^{14}$ Древност Словена доказује њиховим учешћем у готској војсци у борбама против Римљана. ${ }^{15}$ У одељцима о Варјазима говори да је то опште име за северне народе, а да су Варјази-Руси заправо Пруси, који су говорили језиком словенског порекла. ${ }^{16}$

У другом делу књиге Ломоносов хронолошки износи руску историју у време владавине појединих кнежева: Рјурика и његових наследника, Олега, Игора, Свјатослава... до смрти Јарослава Првог. ${ }^{17}$

Врло занимљив и оригиналан детаљ његовог дела представљају и штампани записи у маргинама у којима се паралелно са основним текстом позива на коришћене изворе, што је заправо нека врста претече модерних фуснота.

Поред поменутих дела историјске теме обрађивао је и у радовима: Кратки руски летописаи са родословом, ${ }^{18}$ посвећен великом кнезу Павлу Петровићу; Идеје за слике из руске историје ${ }^{19}$ које су обухватале три групе тема (теме из историје државе - самодржавља и апсолутизма у Русији, теме из националноослободилачке борбе и теме које су се односиле на међународни положај Русије); Опис побуна стрелаиа и владавина изаревине Софије, ${ }^{20}$ сачуван само у француском преводу, будући да је тај рукопис Ломоносов послао Волтеру за писање његове не баш успеле биографије Петра Великог; панегирик Петру Великом који је Ломоносов написао поводом дана крунисања Јелисавете Петровне 1755. године - Похвална реч блаженом и вечнодостојном сећању на императора Петра Великог. ${ }^{21}$

Ломоносов је остао упамћен по томе што је бављење историјом доживљавао као национално позвање. Историја је, по њему, била средство за националну самоспознају и борбу за културну, али и политичку и економску независност Русије.

Норманисти и антинорманисти будућим генерацијама руских историчара оставиће у наслеђе неразрешен спор. Међутим, отварање овог проблема је у руску историографију донело и нов метод и озбиљну критику извора, чега раније није било. Бајер, Милер и Шлоцер с једне стране и Татишчев и Ломоносов с друге стране, у својим расправама су користили најсавременија „средства“ позната ондашњој европској историјској науци. Нерешиви спор нису решили, али научни метод који су они користили остао је њиховим последницима као алатка за изучавање прошлости. Тиме је био прокрчен пут за писање велике синтезе руске историје која је изашла из пера Николаја Михајловича Карамзина.

\footnotetext{
${ }^{14}$ Исто.

${ }^{15}$ Исто, 7-11.

${ }^{16}$ Исто, 41-48.

${ }^{17}$ Исто, 57-144.

${ }_{18}^{18}$ М. В. Ломоносов, Краткий Российский летописеи с родословием, Санктпетербург 1760.

${ }^{19}$ М. В. Ломоносов, Идеи живописных картин из российской истории, Санктпетербург 1764.

${ }^{20}$ Описание стрелецких бунтов и правления цчаревны Софьи.

${ }^{21}$ М. В. Ломоносов, Слово похвальное блаженнья и вечнодостойнья памяти государю императору Петру Великому, Санктпетербург 1755.
} 


\section{Карамзин - Колумбо руске историје}

Када је А. С. Пушкин написао да је Карамзин Русима открио њихову историју, као што је Колумбо Европљанима открио Америку, свакако није мислио да до тада није било писаних руских историја, већ на чињеницу да је Карамзинова Историја руске државе у $^{22} 12$ томова била научно заснована синтеза писана за широку публику. Она је имала огроман одјек и одзив у руској јавности. О томе сведочи податак да је првих 8 томова, који су објављени истовремено 1818. године, било распродато за свега три недеље. Други велики руски песник П. А. Вјаземски Карамзина је назвао другим Кутузовом, јер је Русију „спасао од најезде лаке забаве, призвао је у реалност и показао Русима да имају отаџбину“. Поред тога што је написао до тада најкомплетнију и најобимнију синтезу руске историје, Карамзин, коме је цар Александар I доделио титулу државног историографа, остварио се и на још неколико значајних поља руске културе. Сматра се оснивачем сентиментализма у руској књижевности и реформатором књижевног језика. Покренуо је и уређивао неколико часописа који су имали великог одјека у јавности, а у раној фази свога стваралаштва био је један од најистакнутијих „медија“ идеја Француске револуције међу Русима. ${ }^{23}$

Николај Михајлович Карамзин рођен је 1766. године у селу Михајловка у Казањској губернији, исте оне године када је објављена Ломоносовљева Древна руска историја. Његова породица је старином водила порекло од кримско-татарског кнеза Кара-Мурзе и имала је племићки статус. После доброг кућног образовања четрнаестогодишњи Николај Карамзин је послат у Москву да настави школовање. Предат је на старање у школу-интернат професора московског универзитета Шадена, у којој је учио немачки и француски, истовремено слушајући и предавања на универзитету. По жељи оца 1783. је ступио у војну службу у петроградском гардијском пуку, али војску напушта већ следеће године. Потом се у Москви приближава кружоку окупљеном око чувеног Н. И. Новикова, где прихвата масонске идеје. Заједно са припадницима овог круга учествовао је у издавању првог часописа за децу у Русији Дечја лектира за срие и разум. ${ }^{24}$ После неколико година самообразовања, током 1789. и 1790. пропутовао је Немачку, Швајцарску, Француску и Енглеску. ${ }^{25}$ На почетку овог путовања у Кенигзбергу је упознао Канта, затим је обишао највеће европске градове: Берлин, Лајпциг, Женеву, Париз и

22 Н. М. Карамзин, История государства Российского, Т. I-VIII, Санктпетербург 1818; Т. IX, Санктпетербург 1818; T. X, Санктпетербург 1821; T. XI, Санктпетербург 1824; T. XII, Санктпетербург 1826.

${ }_{23}^{23}$ Ю. М. Лотман, Карамзин, Сотворение Карамзина, Санктпетербург 1997; В. П. Козлов, История государства Российского Н. М. Карамзина в оченке современиков, Москва 1989.

${ }^{24}$ Детское чтение для сердиа и разума, излазио је једном недељно као додатак чувеним Московским вједомостима од 1785. до 1789. У њему је круг окупљен око Новикова излагао своје педагошке и просветитељске погледе који је требало да допру до срца и разума најмлађих. Кроз басне, приче, шале али и популарно излагане природне науке пропагиране су идеје хуманости, човекољубља, поштења и великодушности.

${ }^{25}$ Ю. М. Лотман, Нав. дело, 42-54. 
Лондон, где су га дочекивали и испраћали истомишљеници, упознао са узаврелом интелектуалном климом просветитељства, а потом био и сведок револуционарних догађаја у Француској. ${ }^{26}$ По повратку у Русију покренуо је Московски журнал (1791-1792) и у њему је у наставцима објављивао Писма руског путника, која су далеко надилазила путопис и која су постала буквар руског просветитељстава. ${ }^{27}$ Овај часопис је престао да излази у вези са хапшењем Новикова и забраном рада масонских друштава 1792. године. Наредних неколико година Карамзин је провео на свом имању пишући углавном књижевна дела. Најпознатије међу њима је новела Јадна Лиза, ${ }^{28}$ писана по узору на Гетеовог Вертера, и која се уз остала Карамзинова прозна дела и песме сматра за почетак сентиментализма у руској књижевности. Његова књижевна дела значајно су утицала и на реформу књижевног језика. Престао је да користи црквенословенску лексику и граматику, што ће после полемика које су трајале више од деценије прихватити већина савремених руских писаца, међу којима и сам Пушкин.

Током 1802. и 1803. године издавао је часопис Вестник Европе, у којем је у заступању просветитељских идеја дошао до изражаја његов публицистички дар. Међу чланке који су имали највише одјека спада и његов панегирик Катарини Великој, објављен на почетку владавине Александра I, а који је имао за циљ да новом младом владару укаже на идеје којих би требало да се придржава током своје владавине. ${ }^{29}$

После историјске студије Марфа посадница или покорење Новгорода ${ }^{30}$ коју је Карамзин објавио 1803. године, Александар I му је доделио звање државног историографа, које нико ни пре ни после њега није имао. Уз ову дужност ишла је и плата од 3.000 рубаља, која му је обезбедила материјалну сигурност и све услове за рад. То је био својеврсни „постриг“ међу историчаре, како је приметио поменути Вјаземски. После тога се Карамзин у потпуности посветио писању Историје руске државе. ${ }^{31}$ На том послу је радио до краја живота, повремено се повлачећи из Петрограда на имање своје супруге на којем је сабрао већину доступних извора и имао услове за спокојан рад. Од 1818. године био је члан Императорске академије наука у Петрограду. Умро је 1826. године у Петрограду.

Из саме биографије Карамзина уочљиво је да је био следбеник и заточник идеја рационализма и просветитељства. Оне ће се јасно одразити на његово дело, мада ће, као и сви велики интелектуалци, имати снаге да их учини оригиналним на свом пољу рада, а не само одблеском умствовања својих великих савременика.

Принцип Sine ira et studio, у који се куну сви историописци, формулисао је реченицом да циљ историчара не смеју бити корист и слава, него истина. Ипак,

\footnotetext{
${ }^{26}$ Исто, 57-154.

27 Николай М. Карамзин, Письма русского путешественника, више издања, најновије приредио М. Захаров, Москва 2005.

${ }^{28}$ У Московском журналу излазила је у наставцима, а 1796. је објављена као посебна књига Бедная Лиза, Москва 1796.

${ }^{29}$ Историческое похвальное слово императрице Екатерине II, Вестник Европь, Санктпетербург 1801.

${ }^{30}$ Н. М. Карамзин, Марфа-посадница, или Покорение Новгорода, Санктпетербург 1803.

${ }^{31}$ Ю. М. Лотман, Нав. дело, 565-578.
} 
сматрао је да је историчар у сазнавању те истине донекле ограничен. Он је веровао да историја има идеју-смисао, али пошто је тај смисао замисао провиђења, скривен је од људи. Историчар, по њему, може описивати само људска дела, тј. поступке људи за које они носе моралну одговорност. ${ }^{32}$

Као и његови савременици и узори у Западној Европи Карамзин јасно осећа своју националну припадност и патриотизам сматра једном од највећих врлина. Тако, у Писмима руског путника, када описује повратак у Русију, каже: „Обало, Отаџбино, благосиљам Вас. Остављам све и враћам се у Русију, само да бих говорио руски и слушао Русе. Тешко је наћи град ружнији од Кронштата, али он ми је драг. Овдашњи смештај личи на свратиште нишчих, али у њему је мени весело“. ${ }^{3}$

Пишући Историју руске државе Карамзин је дефинисао свој историографски метод. У њему има и примеса књижевног погледа на стварност, због чега је можда његово дело и имало великог успеха код публике. По њему, при писању историје треба се држати следећих принципа: љубави према отаџбини као делу човечанства; тежити праведности, јер историја није роман, и није парк, где све треба да буде пријатно - она треба да одражава истински свет; треба да покаже шта је било, а не шта је могло бити; треба приказати историју друштва у целости (,успехе разума“", уметност, привреду, законе, обичаје).

Већ из првих редака Историје руске државе препознајемо однос према историји „државног историографа“ и „постриженика међу историчаре“. Он каже: „Историја је у неком смислу света књига народа: главна, неопходна; огледало њиховог постојања и делатности; ризница откровења и правила; завет предака потомству; допуна и објашњење садашњости и пример за будућност“. ${ }^{34}$ Историја за Карамзина очигледно има и духовну и практичну вредност.

По Карамзину, покретачка сила историје је власт - држава оличена у владару самодршцу. Он, као и његови претходници Ломоносов и Татишчев, целокупну руску историју види као сукоб самодржавља са олигархијом и аристократијом. Јачање самодржавља јача и руску државу, а јачање олигархије доводи до њене пропасти. ${ }^{35}$ Отуда он велича готово све руске владаре, самодршце. „Самодржавље је основало и васкрсло Русију“, пише он и у Записима о древној и новој Русији, који су заправо били његов политички али и историографски програм упућен Александру I 1811. године. ${ }^{36}$ У просветитељском духу, на више места у својој историји указује на позитивне и поучне примере. Хвали просвећеност и науку, а осуђује варварство и неукост.

Карамзин је у свом делу недвосмислено прихватио норманско порекло Руса,

\footnotetext{
${ }^{32}$ Н. М. Рогожин, Н. М. Карамзин, Колумбы российских древностей и их современники, у: Историография истории России до 1917. года, Москва 2004, 194.

${ }^{33}$ Н. М. Карамзинъ, Письма русскаго путешественика, С.-Петербургъ 1881, 82.

${ }^{34}$ Исто, Предисловіе, ХІІІ.

35 Сочиненія Карамзина, Исторія Государства Россійскаго (изданіе Александра Смирдина), Т. 1-2, Санктпетрбургъ 1851, Предисловие, XIII-XXXII.

${ }^{36}$ Н. М. Карамзин, Записка о древней и новой России в ее политическом и гражданском отношениях (примечания Ю. С. Пивоварова), Москва 1991, 105.
} 
следио је Милерова и Шлоцерова ${ }^{37}$ истраживања. Шлоцера назива „мужем ученим и славним“ а његово дело „оштроумним““. ${ }^{38}$ Посебно је наглашавао да су његови метод и критика извора били корисни за проучавање руске прошлости. ${ }^{39}$ Норманска теорија није више била у центру пажње јер више није било бироновштине, а Руси су се доказали и остварили на европској сцени као велики народ који покреће и одређује историју. Отуда је Карамзин без комплекса могао прихватити елементе Норманске теорије.

Посебан одељак у уводном делу Карамзин је посветио изворима које је користио. Захваљујући раду претходне генерације историчара који су се бавили руском историјом, њему су били доступни готово сви извори за историју Русије за које се зна и данас, а добрим делом је била извршена и њихова критика. Били су му на располагању грчки, римски, византијски, скандинавски и пољски извори и литература, а користио је и све старе руске летописе и хронике. Од велике користи је била и археографска делатност Н. П. Румјанцева, Мусин-Пушкина и Руског историјског друштва основаног 1804. године. Штавише, Карамзин је користио и

\footnotetext{
${ }^{37}$ Шлоцер (August Ludvig von Sclözer) је као историчар, филолог, статистичар и публициста у европским оквирима остварио значајну каријеру и сматран је једним од највећих ауторитета свога времена за ове области. Био је професор историје и статистике, а касније и државног права на универзитету у Гетингену. Његово животно дело Нестор (Несторъ, Russische Annalen in ihrer Slavonischen Grundsprache vergleichen, übersetzt und erklärt von August Ludwig Schlözer, Göttingen 1802-1809), објављено у 5 томова (1802-1809), садржи све до тада позната верзије Несторовог летописа уз коментаре, поређења са другим изворима који се односе на стару руску историју и Шлоцерове погледе на методологију историјских истраживања и филозофију историје. У Русији је боравио и радио од 1761. до 1767. и постао академик петроградске царске Академији наука. Његов тамошњи рад га је учинио једним од твораца Варјашке теорије порекла Руса. Сматран је за једног од највећих мислилаца епохе просвећености и као професор био је веома популаран, тако да су у Гетинген да слушају његова предавања долазили студенти из Русије и Источне Европе, али и они са Запада. Последњих деценија 18. и почетком 19. века око 900 студената из целе Европе слушало је његова предавања. Међу његовим ученицима били су бројни будући политичари (као, на пример, барон Фон Штајн, покретач чувене Monumenta Germaniae Historica, Харденберг, грофови Стадион, Генц и Рехберг), научници, правници и други „неимари“ 19. века. Оставио је значајан траг на пољима политикологије, публицистике, права и статистике. Међу пасиониране читаоце његових дела многи аутори убрајају и царицу Марију Терезију и њеног сина Јосифа II. Филозофију историје и методолошке поставке Шлоцер је изнео у делу Представе о универзалној историји. Он је први међу западним филозофима историје Словенима доделио значајну улогу у универзалној, светској историји. Ове своје ставове разрадио је у Нестору, где ће наглашавати да се цивилизација шири у таласима, и посебну улогу у историји приписиваће Римљанима, Германима и Словенима као носиоцима и примаоцима ових таласа. Посебно повољно о њему су се изјашњавали Н. М. Карамзин, С. М. Соловјов и М. Н. Пагодин који су њега, а не Татишчева, сматрали родоначелником своје науке. Шлоцерово име било је врло добро познато и међу Србима. Бројни српски студенти који су се крајем 18. и почетком 19. века школовали на протестантским лицејима и универзитетима сретали су се са Шлоцеровим научним радовима, али и његовим публицистичким текстовима. Шлоцер је био у преписци са митрополитом Стратимировићем кога је високо ценио као духовног предводника српског народа, али и као познаваоца словенских старина „који се и сам бави старом словенском историјом“. Српском митрополиту је посветио другу књигу свога Нестора. У посвети он подстиче митрополита да настави рад у науци, како би његов народ добио штампану граматику и речник, а помиње и његове заслуге у издавању Рајићеве Историје и Стојковићеве Фисике.

${ }^{38}$ Сочиненія Карамзина, Исторія Государства Россійскаго, ХXX.

${ }^{39}$ Н. М. Рогожин, Н. М. Карамзин, Колумбы российских древностей и их современники, 196-202.
} 
неке изворе који су страдали у великом московском пожару 1812. године, тако да његово дело има у неким деловима и изворну вредност. У складу са својим историографским концепцијама Карамзин је извршио следећу периодизацију: 1. древни период - од Рјурика до Ивана III; 2. средњи период - од Ивана III до Петра Великог и 3. нови период руске историје - „постпетровски“.

Рад на писању Историје руске државе Карамзин је започео по именовању за државног историографа 1803. године. Због рата са Наполеоном 1812. био је принуђен да прекине рад. Када се 1816. вратио у Петроград, имао је написаних 9 томова, али је првих 8 објавио заједно 1818, а потом и 9. том. Следећа 3 тома објављена су до 1826 . године. ${ }^{40}$ Иако је писао готово до саме смрти, он није успео да заврши своје дело, имајући у виду поменуту периодизацију, већ га је у 12 томова довео до Смутнога времена закључно са догађајима 1611-1612.

У првом тому обрађена је догађајна и друштвена историја од описа староседелаца Русије, историја Словена од првих помена, доласка Рјурика и његове браће у Русију па до краја владавине великог кнеза Владимира 1014. године; други том обухвата период од великог кнеза Свјатоплука до Владимира Мономаха (11151169); у трећем тому описана је историја од великог кнеза Андреја (1169) до краја владавине великог кнеза Георгија Всеволодовича (1238); четврти том описује догађаје од почетка владавине великог кнеза Јарослава II Всеволодовича (1238) до краја владавине великог кнеза Димитрија Константиновича (1362); у петом је изложен период јачања Московије од Димитрија Донског (1363) до Василија Васиљевича Тамног (1462), при чему је додата и друштвена историја Русије од монголске најезде до доласка на власт Ивана III; шести том обухвата владавину Ивана III (1462-1505); седми том је посвећен владавини Василија III (1505-1533), али и друштвеној историји Русије под Иваном III и Василијем III; читав осми и девети том описују владавину Ивана IV Грозног (1533-1584); десети том посвећен је царствовању Фјодора I Ивановича (1584-1598), при чему је дат и преглед стања руског друштва у другој половини 16. века; у једанаестом тому приказане су владавине Бориса Годунова (1598-1605), Фјодора II (1605), и Лажног Димитрија (1605-1606) а последњи, дванаести, недовршени том описује наставак Смутног времена и царствовање Василија Шујског (1606-1610), и делимично интеррегнум до 1612.

Историја руске државе Николаја Михајловича Карамзина била је прва велика синтеза руске историје, писана на основу извора, али разумљивим и широком кругу читалаца занимљивим стилом. Ово дело имало је огроман утицај на руско друштво у 19. веку. Одмах по објављивању постало је обавезно штиво на свим вишим школама и универзитетима у Русији. До дубоко у 19. век није било превазиђено, нити је написана слична синтеза. Историографски радови који су настали у првим деценијама после њега углавном су се бавили полемиком са неким његовим деловима или Карамзиновим ставовима. На основу његовог дела написано

40 H. М. Карамзин, История государства Российского, Т. I-VIII, Санктпетербург 1816; T. IX, Санктпетербург 1818; Т. Х, Санктпетербург 1821; Т. ХІ, Санктпетербург 1824; Т. ХІІ, Санктпетербург 1826. 
је и неколико краћих извода, попут Историје Русије у причама за деиу ${ }^{41}$ Александре Јосифовне Ишимове. Карамзиново дело је и крајем 19. века, када су већ биле написане много модерније синтезе С. М. Соловјова, Н. И. Костомарова и В. О. Кључевског, наставило да живи упоредо с њим.

На Карамзиновој Историји руске државе васпитано је више поколења руских књижевника и уметника и формирана је историјска свест либералног грађанства 19. века. О овом делу као извору својих историјских сазнања са уважавањем су писали: Л. Н. Толстој, И. А. Гончаров, С. И. Аксаков, Ф. М. Достојевски, Н. А. Доброљубов, Н. Г. Чернишевски, М. Е. Салтиков-Шчедрин, П. П. Семјонов-Тјан-Шански, К. Н. Бестужев-Рјумин, С. М. Соловјов и многи други значајни делатници руске културе њеног ,златног“ и „,сребрног“ века. ${ }^{42}$ Сличан одјек у српском друштву прве половине 19. века имала је Историја Јована Рајића, која такође дуго није била превазиђена, већ су само прављени изводи из ње, и на њој су такође националну свест формирале генерације делатника српске културе до дубоко у 19. век.

${ }^{41}$ А. И. Ишимова, История России в рассказах для детей, Санктпетербург 1841.

${ }^{42}$ Н. М. Рогожин, Нав. дело, 217-219. 


\title{
WRITERS OF RUSSIAN HISTORY: M. V. LOMONOSOV AND N. M. KARAMZIN
}

\begin{abstract}
Summary
This work examines the history writing of Mikhail Vasilyevich Lomonosov and Nikolay Mikhailovich Karamzin. Besides a brief review of their biographies and work in other fields of Russian culture and science, an examination is made of their historiographical method, the sources they used, and the intellectual influences which shaped their thinking. Lomonosov, who wrote his most significant historiographic work Ancient Russian History in the mid-18th century, was an ardent opponent of the Normanist theory of Russian origins. Karamzin, who published his 12-tome History of the Russian State in the 1820 s and 1830 s, accepted this theory fully.
\end{abstract}

Keywords: Mikhail Vasilyevich Lomonosov, Nikolay Mikhailovich Karamzin, history of Russian historiography, history of 18th- and 19th-century Russian culture, Varangian question, Catherine the Great, Alexander I. 